cinema of actuality 
asia-pacific: culture, politics, and society

Editors: Rey Chow, Michael Dutton, H. D. Harootunian, and Rosalind C. Morris 


\section{cinema of actuality}

JAPANESE AVANT-GARDE FILMMAKING

IN THE SEASON OF IMAGE POLITICS

yuriko furuhata

DUKE UNIVERSITY PRESS | DURHAM AND LONDON | 2013 
(C) 2013 Duke University Press

All rights reserved

Printed in the United States

of America on acid-free paper @

Designed by Amy Ruth Buchanan

Typeset in Whitman by Tseng

Information Systems, Inc.

Library of Congress Cataloging-in-Publication Data

Furuhata, Yuriko, 1973-

Cinema of actuality : Japanese avant-garde

filmmaking in the season of image politics /

Yuriko Furuhata.

pages $\mathrm{cm}$-(Asia-Pacific : culture, politics, and society)

Includes bibliographical references and index.

ISBN 978-o-8223-5490-1 (cloth : alk. paper)

ISBN 978-o-8223-5504-5 (pbk. : alk. paper)

1. Motion pictures-Japan-History-2oth

century. 2. Motion pictures - Political aspects-

Japan-History-2oth century. I. Title. II. Series:

Asia-Pacific.

PN1993.5.J3F859 2013

$791.430952-\mathrm{dc} 23$

2013011687 